\title{
Civilization and barbarism
}

\author{
Carlo Ginzburg \\ UCLA, California, USA / \\ Scuola Normale Superiore di Pisa, Italy \\ Piazza San Martino 1, Bologna 40126, Italia \\ e-mail: ginzburg@history.ucla.edu
}

\begin{abstract}
The reflections on civilization, barbarism, and their intricate relationship, which were put forward in ancient Greece, from Herodotus to Aristotle, had a longterm impact. In the mid-16th century debate which took place in Valladolid, between Juan Ginés de Sepúlveda and Bartolomé de Las Casas, about the status of the native populations of the New World, the Latin translations of Aristotle's Politics, and its comment by St. Thomas Aquinas, proved to be especially relevant for both opponents. Were Indian natives comparable to Aristotle's "natural slaves"? Was the war against them comparable to hunting wild beasts? The paper focuses on the debate and its contemporary implications.
\end{abstract}

Keywords: Aristotle; Bartolomé de Las Casas; Juan Ginés de Sepúlveda; simpliciter and secundum quid; Thomas Aquinas

Civilization, barbarism, and: does 'and' connect or disconnect? Does civilization stand in opposition to barbarism or must we consider that the relationship is altogether more complicated? And if so, why?

1. We are used to thinking that the opposition between civilization and barbarism came to us from the Greeks. But a reflection on its ambiguities is also part of the Greek legacy: its troubling implications still resonate with us.

Here is a story told by Herodotus, "the father of history" (a long debated, but well-earned title), in the third volume of his Histories $(3,38)$. It is a digression that is preceded by a detailed list of crimes committed by Cambyses, the Persian king: murder of his brother, incest with his sisters, violating cadavers, defiling the images of the gods. Cambyses, Herodotus concludes, was mad. An example follows: 
I hold it then in every way proved that Cambyses was very mad; else he would never have set himself to deride religion and custom. For if it were proposed to all nations to choose which seemed best of all customs, each, after examinations made, would place its own first; so well is each persuaded that its own are by far the best. It is not therefore to be supposed that any, save a madman, would turn such things to ridicule. I will give this one proof among many from which it may be inferred that all men hold this belief among their customs: - When Darius was king, he summoned the Greeks who were with him and asked them what price would persuade them to eat their fathers' dead bodies. They answered that there was no price for which they would do it. Then he summoned those Indians who are called Callatiae, who eat their parents, and asked them (the Greeks being present and understanding by interpretation what was said) what would make them willing to burn their fathers at death. The Indians cried aloud, that he should not speak of so horrid an act. So firmly rooted are these beliefs; and it is, I think, rightly said in Pindar's poem that custom is the queen of all things. (Herodotus 1982[ca 425 BC]: 51 [1, III])

That Darius, king of the Persians, actually attempted such an act appears to be highly unlikely; be that as it may, we will never succeed in reaching certainty on the matter. It is more important to understand the significance of his speech within Herodotus' historical narration. Pindar's formula, according to which "custom is the queen of all things" - nomos ho panton basileus - would lead us to conclude that all customs are equal, and therefore it is impossible to draw a clear boundary between customs which would be acceptable and those which would not (Nippel 1996; Humphreys 1987). In other words, our habits seem obvious and natural to us, insofar as they are, like all habits, the result of convention.

And yet, attributing to Herodotus a point of view which we would call radically relativistic, would be risky. It is worth remembering a remark by Arnaldo Momigliano: "Herodotus, one of the founding masters of ethnography, was ready to declare 'barbarian' customs superior to the Hellenic ones. But it was a cool, ultimatedly selfassured, look, at foreign civilizations. There was no temptation to yield to them" (Momigliano 1980: 518-519).

It is the cold look of someone who stages a mental experiment that addresses, on a small scale (but through an extreme example, namely funeral rites), a more general issue: the variety of human customs. On this point, Darius, the king of Persia, appears as a double, an alter ego of Herodotus, the Greek historian. They are both simultaneously the judge and the judged, inside and outside the experiment. When Herodotus says that custom is "the queen of all things" he simultaneously detaches himself from all things and observes them from afar. We see, looming in the distance, an ongoing dialogue between Herodotus and the sophists, who put forward paradoxes 
like: "A Cretan says: all Cretans are liars." ${ }^{28}$ Is the Cretan lying or is he telling the truth? What does Herodotus think? ${ }^{29}$

2. The paradox of the Cretan has never ceased to torment logicians: the paradox of Herodotus torments, or should torment, historians and anthropologists. But the unsettling feeling, which we feel in reading the aforementioned passage, that we are facing something contemporary, must be limited by pointing out an element of distance, which is linked to the term nomos. The translations of law or custom are inevitably inadequate, because the term nomos refers to an undifferentiated sphere in which 'right', 'custom' and 'religion' (in the sense in which we use these terms) mingle. Nomos is a noun derived from the verb nemein: divide (or allocate) according to the law or tradition (Benveniste 1948: 79, 1969: 85; Laroche 1949). We are seemingly back to our starting point, but after having acquired a piece of information: the association between law, custom, and division. Even when they look innocent, classifications (and especially dichotomous classifications) have often, although not always, political implications. In a famous passage from his dialogue The Statesman [Politikos], Plato introduces dichotomous categories into the discussion, aptly beginning with the one which contrasts Greeks and barbarians, through an objection which is formulated by one of the dialogue's interlocutors, named, significantly, the Stranger:

[...] it is very much as if, in undertaking to divide the human race into two parts, one should make the division as most people in this country do; they separate the Hellenic race from all the rest as one, and to all other races, which are countless in number and have no relation in blood or language to one another, they give the single name 'barbarian'; then, because of this single name, they think it is a single species. Or it was as if a man should think he was dividing number into two classes by cutting off a myriad from all the other numbers, with the notion that he was making one separate class, and then should give one name to all the rest, and because of that name should think that this also formed one class distinct from the other. A better division, more truly classified and more equal, would be made by dividing number into odd and even, and the human race into male and female; as for the Lydians and Phrygians and various others they could be opposed to the rest and split off from them when it was impossible to find and separate two parts, each of which formed a class. (Plato 1975[ca 350 BC]: 262d-263a) (30 $^{30}$

28 Nippel 1996: 174: “[...] there are discussions proposed by the sophists on the relativity of law (dissoi logoi) that refer to examples mentioned by Herodotus". On dissoi logoi, see Untersteiner 1967: 161-172.

29 Here I pick up some remarks developed in Ginzburg 2006.

30 Cf. Lloyd 1966. A reference to this passage can be found also in Pagden 1986: 123-124. 
3. On this page Plato rejects the holistic opposition between 'us' and 'them', between Greeks and barbarians, as poorly argued, and therefore untenable. The opposition, and its hierarchical implications, had been reinforced by the wars between the Greeks and Persians. Like Herodotus, although in a different manner, Plato responds to the challenge of the sophists. Today, this term immediately evokes the noun 'sophistry', with its negative connotations - an oblique and distant echo of the negative aura that surrounded the sophists, philosophers who roamed Greece, teaching eloquence. In return for their teaching, the sophists asked for payment: a novelty which created a scandal and cast an enduring shadow on their image. But the theories that the sophists proposed were scandalous as well, because they questioned allegedly self-evident ideas, such as the opposition of Greeks and barbarians - and more generally, the relationship between nomos and physis, law and habit on the one hand, nature on the other. "Could what we consider natural be on the contrary the product of convention?" argued the sophists. That is the question that Herodotus asked himself in staging the (presumably fictional) experiment staged by Darius, the Persian king.

Since a long time, historians of philosophy have dispelled the negative stereotypes that tradition had projected onto the sophists. Today, their questions seem more urgent than ever, even if our answers greatly differ from theirs. Certainly, we must be wary of false continuities, like those tied to language, as in the case of nomos/law/habit. And the Greek term physis, which we translate as 'nature', has a different meaning for us than it did for the ancient Greeks. Today, somebody could translate the opposition between physis and nomos, nature and convention, into a question rife with political implications: "Do cultural differences have a biological origin?" A translation that would amount to a blatant anachronism. Let us have a quick look at the historical sequence.

4. In his Statesman, Plato had opposed the natural dichotomy between men and women to the fictitious divide between Greeks and Barbarians. At the beginning of Politics, Aristotle cites the distinction between men and women, and the superiority of one over the other, to introduce by way of analogy the distinction between masters and slaves, i. e. between "natural ruler and natural subject [...]. One that can foresee with his mind is naturally ruler and naturally master, and one that can do those things with his body is subject and naturally a slave". For Aristotle, slavery is a natural phenomenon, like being a woman. Between these two forms of subordination, there exists yet another profound similarity: "among barbarians, the female and the slave have the same rank", because barbarians "have no class of natural rulers". The community that characterizes barbarian societies is a community of slaves. Aristotle cites approvingly a line from Euripides (Iphigenia in Aulis, line 1400): “Tis meet that Greeks should rule barbarians" (Aristotle 1959[ca 325 BC]: 1252 a 26-1252 b 11). 
Today hardly anyone would claim that slavery is a natural phenomenon. Moreover, questions about the role played by cultural elements in the opposition between men and women have been around for a long time. But other statements within Aristotle's vast oeuvre end up contradicting those which have been just mentioned.

Once again, we are confronted with an answer to the challenge posed by sophists. Their affirmations, deliberately provocative, about the relation between nomos (law/constitution) and physis (nature), claimed the human access to reality as selfevident, like in the reference to Pindar's words, "Custom is the queen of all things". But Aristotle, in his Peri hermeneias [On Interpretation], focused on the language and the problematic relationship between language and meaning. Referring to a statement from Plato's dialogue The Sophist, Aristotle observed that a noun taken alone and out of context can neither be true or false, "unless one adds that it is or is not, absolutely speaking (haplos) or referring to time (kata chronon)" (see Ginzburg 2001: 25-61). With this distinction, the issue addressed by the sophists - the distinction between physis (nature) and nomos (law/custom) - was tacitly shifted from the ontological to the epistemological level, from reality to discourse. ${ }^{31}$

On the surface, this argument looks purely technical; in fact, it amounted to a turning point in the history of thought, even if it was neither presented nor perceived as such for a long time. Looking back, it looks like a bomb that would end up exploding nearly two thousand years later. In his Latin translation of Aristotle's Peri hermeneias, Boethius (who lived between the 5th and the 6th centuries CE) translated the distinction between haplos and katà chronon as simpliciter (absolutely) and secundum quid (according to the circumstances). The latter term expanded to a larger scale the general characterization indicated by Aristotle.

Generation after generation of students read Aristotle's On Interpretation in Boethius' Latin translation (De interpretatione). Two of them would end up being the protagonists in the famous debate which took place in Valladolid, at the behest of Charles V, in 1550-1551: Juan Ginés de Sepúlveda, translator of and commentator on Aristotle, and the Dominican friar Bartolomé de Las Casas, bishop of Chiapas.

5. Sepúlveda and Las Casas were at odds on two issues: could one consider the Indians of the New World slaves by nature, and was a war against them a just war? These two questions presupposed a third: should one regard Indians as barbarians? On these questions (as well as on many others, more or less related to these), the two interlocutors took diametrically opposed positions: Sepúlveda argued for the Indians' natural inferiority, whereas Las Casas fought for their rights, making a decisive contribution (as it is widely considered today) to the idea of human rights (see Baccelli

31 Aristotle's distinction may have been inspired by a passage of Dissoi logoi $(5,15)$, a sophist treatise; cf. Robinson 1979: 131, 208-9. 
2008). Still, Sepúlveda and Las Casas spoke a common tongue, made up of shared cultural references: not only Aristotle, but Aristotle read through St. Thomas Aquinas.

6. Thomas' reading of Aristotle was an act of intellectual appropriation that had profound intellectual and political consequences. His commentary on the first chapter of the first book of Aristotle's Politics, dealing with "barbarians", was especially important. Thomas asked for a definition of 'barbarian', and then replied, quoting St. Paul (1 Cor. 14: 10-11):

However many the languages used in the world, all of them use sound; but if I do not understand the meaning of the sound, I am a barbarian to the person who is speaking, and the speaker is a barbarian to me. (The New Jerusalem Bible 1985)

One would be tempted to conclude, by removing this passage of Paul (who spoke Hebrew, Latin and Greek) from its context, that anyone may be a barbarian to others, regardless of who he is, as long as he does not understand the others' language. It is difficult to imagine a more radical contestation of the idea of barbarism (and of natural barbarism) put forward by Aristotle. But Thomas did not stop there: the very interpretation of barbarism was debated. According to some, he wrote, barbarians are those who speak their language but do not know how to read or write: which is why the Venerable Bede translated the liberal arts into a vernacular language, to help the natives break free of their barbarism. Therefore, Thomas went on, by 'barbarian' one means 'aliquid extraneum', something foreign to us: the other. It seems as if Thomas is referring back to St. Paul, but instead it is Aristotle who is surfacing again: extraneus (other) can be meant as either simpliciter, absolutely, or quo ad aliquem, in relation to someone. From an absolute point of view, Thomas argued, we say that those who are strangers to the human race are such because they lack reason, "or because they live in a part of the world that is not temperate (propter regionem aliquam intemperatam)", whose characteristics most often deprive inhabitants of intelligence, or because certain deficient customs one finds in certain lands render their inhabitants "irrational and nearly bestial (irrationales et quasi brutales)". Men deprived of reason ignore both law and writing (Thomas Aquinas 1492[ca 1272]: c. 4v).

The emergence of a geographical dimension - as imprecise as it may be - within Thomas' argumentation explains how Sepúlveda, in his Apologia, published in Rome in 1550, was able to cite the aforementioned page by Thomas in order to support his thesis, that war against the Indians was just (Sepúlveda 1975[1550]). Was it an unfounded reference? Certainly not, although Thomas could not foresee how his own reflections would be used almost three hundred years later, to justify the Spanish conquest of the New World. 
7. In the Apologia Sepúlveda took up the thesis of another Latin dialogue of his, the Democrates secundus, that had given rise to a series of such biting critiques that it was not granted a printing (Sepúlveda 2009[1544]). In turn, Bartolomé de Las Casas responded to Sepúlveda's Apologia - a Spanish version of which he could have read with a Latin Apologia, which also went unpublished (Las Casas 1975[1551]). It opens on a presentation of theses by Sepúlveda, followed by an impassioned and extremely detailed refutation, starting from those concerning barbarism.

Las Casas distinguished different uses of the term 'barbarism'. According to the first, barbarism is synonymous with ferocity, and can therefore be applied to everyone and anyone, including (Las Casas observed contentiously) the Spanish, for the way in which they acted toward the Indios. According to the second meaning (continues Las Casas, following the commentary of St. Thomas on Aristotle's Politics), barbarism refers to those who do not possess a written language. He who does not understand another's language is a barbarian, as St. Paul says: it is in this sense that John Chrysostom may label the Three Wise Men as 'barbarians'. And Las Casas (1975[1551]: c. 15r) commented:

These barbarians are not barbarians simpliciter, absolutely, but rather barbarians secundum quid: and therefore they are not to be spoken of as proper barbarians, but as barbarians due to a series of accidental circumstances, ex accidenti. ${ }^{32}$

Las Casas took up the distinction introduced by Aristotle in his Peri hermeneias, translated by Boethius and commented by Thomas. Recalling this Aristotelian origin is not irrelevant. To speak of a "traditional Thomist distinction", as Anthony Pagden (1986: 126) did, would distort the meaning of the discussion between Sepúlveda and Las Casas.

Las Casas used the distinction between simpliciter and secundum quid to distance himself from the Aristotelian Sepúlveda and his identification of the Indios with Aristotle's barbarians as "slaves by nature". "It is absolutely evident," Las Casas observed, that the "barbarians by nature" mentioned in the first book of Politics have nothing to do with the barbarian monarchies (barbarorum regna) talked about in the third book: kingdoms resembling tyrannies and yet different, observes Aristotle, because they "govern according to law and are hereditary" (Aristotle 1959 [ca 325BC]: 249). But in the Latin Apologia of Las Casas, the passage from Aristotle is cited in a slightly different form: "legitimate and conforming to the mores of the country"

32 "Huiusmodi barbari non simpliciter sed secundum quid barbari dicuntur: hoc est non sunt proprie barbari, sed ex accidenti [...]”. Cf. Aristotle 1959[ca 325 BC]: 1285 a. 
("legitima et secundum morem patriae"). ${ }^{33}$ The motive is simple: Las Casas had read a Latin version of Politics translated by the humanist Leonardo Bruni, offered in 1438 to Pope Eugen IV, and printed with Thomas' commentary first in Rome, in 1492, then in Venice, in 1500 (Vasoli 1972: 629). ${ }^{34}$ Bruni (followed by Las Casas) misunderstood the meaning of the adjective patrikai in Aristotle's passage (1285 a19), linking it to the 'fatherland' (secundum morem patriae) rather than to the 'hereditary' transmission of the father to the son. Thomas, who had read and commented Aristotle's Politics in the literal translation of William of Moerbeke, did not commit such a mistake. One can assume that Bruni's mistranslation comes from another passage of Aristotle that Las Casas does not cite, in which these barbarian monarchies were identified as Asian monarchies:

[...] for because the barbarians are more servile in their nature (physei) than the Greeks, and the Asiatics than the Europeans, they endure despotic rule without any resentment. (Aristotle 1959[ca 325BC]: 249)

Las Casas argued - against Aristotle, who took the natural barbarism of Asian peoples as a given - that these "legitimate" monarchies (katà nomon), made possible by the "character naturally more servile" (physei) of Asian populations, were merely cases of barbarism secundum quid. ${ }^{35}$ In other words, Las Casas took advantage of a conceptual tool forged by Aristotle in order to distance himself from its creator, Aristotle, and his interpreter, Sepúlveda. ${ }^{36}$

8. Starting from the passage about the barbarian monarchies we find in the third book of Aristotle's Politics, Las Casas proposed a double analogy with the Indios of the New World. On the one hand, a negative analogy: the Indios are spared the stigma of absolute barbarism - barbarism simpliciter - to which Sepúlveda had condemned

33 Las Casas 1975[1551]: c. 15v: "apud quosdam barbaros regna vim habentia proxima tyrannidi licet sint legitima et secundum morem patriae". Pagden (1986: 132) translates this as: "legitimate and paternal [in origin]", going back to a passage of commentary by St. Thomas that Las Casas cited in his Apologia (but we find no trace of this citation).

34 Thomas Aquinas, Commentaria... in octo Politicorum Aristotelis libros cum textus eiusdem. Interprete Leonardo Aretino, colophon: "impressum est hoc opus Romae per magistrum Eucharium Silber alias Franck, xiiii kal. Aug. 1492", c. 85 v. (I consulted the copy held at the Biblioteca Comunale degli Intronati in Siena, a-z8 A-I8).

35 Pagden (1986: 236, note 44) writes that William of Moerbeke, followed by Las Casas, would have been guilty of a "deliberate distortion of Aristotle's text"; but Las Casas had read a different translation.

36 Thomas Aquinas, Commentaria, c. 85 v: "secundum legem et secundum leges patrias. Dicunt autem leges patriae consuetudines, quae descendunt a parentibus in filios" (cf. Thomas Aquinas 1951: 170). 
them. On the other hand, a positive analogy: like the barbarian monarchies described by Aristotle, the Indios have a "legitimate, just and natural principle" (Las Casas 1975[1551]: c. 22r). The qualities that Las Casas famously recognized in these populations, namely their gentleness and their ease with the mechanical arts, were in a certain sense the corollary of their identification with a relative, "secundum quid" barbarism.

This looks like a decisive point, because it clarifies an apparent contradiction in Las Casas' discourse. When we deal with the barbarians, he wrote, we must refrain from acts of repression, as the philosopher (that is, Aristotle) argues: we must coax them and lead them lovingly toward proper mores. Barbarians were also created in the image of God. Faced with human beings, whoever they may be - including those plunged in the most extreme barbarism - we must demonstrate Christian charity. Once again, Las Casas quoted St. Paul from memory, mixing up passages from the Epistle to the Romans (Rom. 1: 14-15), the Epistle to the Galatians (Gal. 3: 28-29) and the Epistle to the Colossians (Col. 3: 11):

I have an obligation to Greeks as well as barbarians, to the educated as well as the ignorant and hence the eagerness on my part to preach the gospel [...] There can be $[\ldots]$ neither male nor female [...] there is no room for distinction between Greek and Jew, between the circumcised and uncircumcised, or between barbarian and Scythian, slave and free. There is only Christ: he is everything and he is in everything. (The New Jerusalem Bible 1985)

Here, Las Casas marked an unfathomable distance between Aristotle and himself:

Even if the philosopher, who knew neither of Christian charity nor the truth, wrote that knowledgeable people could hunt barbarians as one hunts wild beasts, nobody should think that it would be allowed to kill barbarians or treat them with harshness as if they were mares. (Las Casas (1975[1551]: c. 21r).

Las Casas is alluding to a passage from the first book of Aristotle's Politics. Sepúlveda had also cited it in his Democrates secundus, which Las Casas had been unable to read (Sepúlveda 2009[1544]: 35). A terrible passage, which must be cited in its entirety:

If therefore nature makes nothing without purpose or in vain, it follows that nature has made all the animals for the sake of men. Hence even the art of war will by nature be in a manner an art of acquisition (for the art of hunting is a part of it) that is properly employed both against wild animals and against such of mankind as though designed by nature for subjection refuse to submit to it, inasmuch as this warfare is by nature just. (Aristotle 1959[ca 325 BC]: 1256 b 21-27) 
"Farewell, Aristotle (Valeat Aristoteles)," wrote Las Casas (1975[1551]: c. 21r). In the edition of Politics translated by Leonardo Bruni - which Las Casas had read - the passage which I just cited was accompanied by a commentary by St. Thomas. A few, laconic sentences:

Hunting is necessary amongst beasts that are naturally subject to man, as well as against barbarian men who are naturally slaves, as one has already stated; and if such a war ever takes place, it is a just war. ${ }^{37}$

St. Thomas commented on Aristotle; he did not judge him. Las Casas, a just and brave man, may have read these statements with horror. But he could have never written: "Farewell, St. Thomas."

9. Between Greek ethnocentrism and Christian universalism there lies an abyss; but one must be wary of oversimplifications. Las Casas quoted the words of St. Paul before Christ, there are neither slaves nor free men - and contrasted Christian charity with the harshness of Aristotle. But Thomas, not just a Christian, but a canonized saint, had not distanced himself from Aristotle, according to whom a war against slaves by nature, compared to wild beasts, is a just war. But hadn't Las Casas learned from Aristotle himself that one could consider the Indios barbarians secundum quid, ruled by a power similar to tyranny, but nevertheless legitimate? These are historical, not logical, contradictions.

10. Two traditions (at least) superimposed in time and space. Aristotle's Peri hermeneias, translated by Boethius, is an example of the way in which Greek and Latin traditions intertwined. But it is an extremely valuable example, since the distinction between simpliciter and secundum quid possesses a meta-linguistic value: it allows reflection on this intricate relationship from a distance. We may wonder whether other cultures have come up with a distinction analogous to this one. (To put it into practice in one's daily life does not necessarily imply articulating it in explicit terms.)

37 Thomas Aquinas (1492[ca 1272]), Commentaria, c. 14r: "et pars eius est praedativa, qua oportet uti ad bestias que naturaliter sunt subiecte hominibus et ad homines barbaros qui sunt naturaliter servi, ut supradictum est; et si hoc bellum sit [,] iustum secundum naturam [est]". This integration may refute the hypothesis advanced by Richard Tuck (1999: 71-72) according to which this version, which he quotes from the Venice edition of 1506, c. 9 (but the error "secundam Naturam" must be corrected), would be the result of an editorial intervention from the humanist era, modifying the original version: "Ac si hoc bellum primum sit iustum secundum naturam" (as in, for example, Egregii doctoris sancti Thome de Aquino In libros polithicorum Ar[istotelis] comentum foeliciter incipit, Barcelona, 1478). Tuck refers, in a general manner, to Martin 1952, an essay which remains fundamental. 
As I argued elsewhere, Erich Auerbach, in his famous essay "Figura" (1938) reread the interpretation of the Scripture proposed by St. Augustine through Erwin Panofsky's famous essay "Perspective as symbolic form" (Ginzburg 2013). Reading the Old Testament as a part of the New Testament, as St. Augustine proposed, meant emphasizing that the Hebrew Bible had been true in the past, but that its truth had been overtaken by Christian revelation. Therefore, in commenting on Augustine's reading (which ended up, through Hegel, contributing to form our own attitude with regard to history), I myself proposed the metaphor of 'perspective' - even if the metaphors used by Augustine are musical, not visual (Ginzburg 2001: 155). This perspectivism implies a hierarchy, as in Christianity's self-definition as Verus Israel. Could we broaden this conclusion to perspective understood at a literal level?

11. The answer to these questions leads us, once again, to the distinction articulated by Aristotle, translated by Boethius and commented by Thomas: the distinction between simpliciter and secundum quid. I cite it here in Latin, in Boethius' translation, because that is what Las Casas did in several instances. He did it also in discussing a most delicate issue: human sacrifices practised by the Indios. Indeed, in commenting on this passage Tzvetan Todorov (1982: 195) spoke, with a certain embarrassment, of 'perspectivism': “it is truly surprising to see 'perspectivism' introduced into a field so inappropriate for it".

But let us look more closely at what Las Casas wrote. I will cite a brief excerpt from his response to objections addressed to him by Sepúlveda during the Valladolid debate:

As for what he [Sepúlveda] says about the probable opinion, etc., I say that when any population, whatever it may be, argues about the probable opinion, it does not do so with regard to the rules of simpliciter reason, but because it seems to the population that it is the way to go, and that the argument is used and approved by those who are experts in an activity or art, even if they end up being mistaken. (Las Casas 1992[1552]: 178)

In other words, Las Casas considers human sacrifices from a secundum quid perspective, which, however, presupposes an absolute perspective (simpliciter), founded on the rules of reason - and not on those of Christian religion.

12. This link between simpliciter and secundum quid is implicit in a text which was able to unfold in the most profound way the implications of the linear perspective as cognitive model, i. e. the dedicatory epistle which precedes Niccolò Machiavelli’s The Prince: 
Nor do I want it to be reputed presumption if a man from a low and mean state dares to discuss and give rules for the government of princes. For just as those who sketch landscapes place themselves down in the plain to consider the nature of mountains and high places and to consider the nature of low places place themselves high atop mountains, similarly, to know well the nature of peoples one needs to be prince, and to know well the nature of princes one needs to be of the people. (Machiavelli 1998[1513]: 4)

Long time ago the words "sketch landscapes" were interpreted as an allusion to Leonardo da Vinci, whom Machiavelli had met in Imola, at the court of Cesare Borgia, in 1503. But Machiavelli had also definitely in mind Aristotle's Politics, read (as Las Casas had done) in Leonardo Bruni's Latin translation, commented by St. Thomas. Perspective, far from being egalitarian, is truly hierarchical, and allows us to grasp the "effectual truth of the thing" (verità effettuale della cosa) from a specific point of view. Machiavelli, one could say, integrated simpliciter and secundum quid (see Ginzburg 2015).

13. But what about the barbarism of today? Massive migratory currents have been mixing human beings from different cultures. How should we face this diversity? One can imagine two opposing attitudes: to impose our point of view, or to tolerate all behaviours whatever they may be, even those the most removed from our own. Neither of these two solutions seems satisfactory; but a poorly sketched compromise between the two seems even less so. The only acceptable solution seems to be a secundum quid behaviour, on a case-by-case basis. Here, casuistry may prove to be helpful. Struck dead by Pascal's Provinciales, casuistry (the Jesuits', but others' as well), came back to life in the context of bioethics. ${ }^{38}$ Bioethics teaches us that the Islamic veil and genital mutilation (to take two examples) cannot be placed on the same level. We must learn from the Jesuits, and from Pascal. ${ }^{39}$

38 I reflected on these subjects in the Tanner Lectures I gave at Harvard in 2015 (Ginzburg in print).

39 Acknowledgements. I would like to thank Maria Luisa Catoni and Sergio Landucci for their critical remarks, and Allen Boxer for his translation. A preliminary French version of this text was presented at the MuCEM de Marseille on March 13, 2014, as part of the cycle "Civilization and barbarism", organised by Tzvetan Todorov, see http://en.calameo.com/ books/00235837689dd10169a80 (July 6, 2017). 


\section{References}

Aristotle 1959[ca 325 BC]. Politics. (Rackham, H., trans.) Cambridge: Harvard University Press. Baccelli, Luca 2008. Guerra e diritti: Vitoria, Las Casas e la conquista dell'America. Quaderni fiorentini per la storia del pensiero giuridico moderno 37: 67-101.

Benveniste, Émile 1948. Noms d'agent et noms d'action en indo-européen. Paris: AdrienMaisonneuve.

- 1969. Le vocabulaire des institutions indo-européennes. Vol. 1. Paris: Minuit.

Ginzburg, Carlo 2001. Wooden Eyes: Nine Reflections on Distance. New York: Columbia University Press.

- 2006. Lost in translation: Us and them. Hermitage 2: 20-22.

- 2013. Le forbici di Warburg. In: Catoni, Maria Luisa; Ginzburg, Carlo; Giuliani, Luca; Settis, Salvatore, Tre figure: Achille, Meleagro, Cristo. Milan: Feltrinelli, 109-132.

- 2015. Intricate readings: Machiavelli, Aristotle, Thomas Aquinas. Journal of the Warburg and Courtauld Institutes 78: 157-172.

- (in print). Casuistry, For and Against: Pascal's Provinciales and Their Aftermath. Tanner Lectures.

Herodotus 1982[ca 425 BC]. Herodotus. Vol. 2. (Books III, IV.) (Godley, Alfred Denis, trans.). Cambridge: Harvard University Press.

Humphreys, Sally 1987. Law, custom and culture in Herodotus. Arethusa 20: 211-220.

Laroche, Emmanuel 1949. Histoire de la racine -nem en grec ancien: nemo, nemesis, nomos, nomizo. Paris: Klincksieck.

Las Casas, Bartolomé de 1975[1551]. Apologia. In: Losada, Ángel, (ed.), Juan Ginés de Sepúlveda - Bartolomé de Las Casas, Apologia. Madrid: Editora Nacional.

- 1992[1552]. Obras completes. Vol. 10: Tratados de 1552. (Hernández, Ramón; Galmés, Lorenzo, eds.) Madrid: Alianza.

Lloyd, Geoffrey Ernest Richard 1966. Polarity and Analogy: Two Types of Argumentation in Early Greek Thought. Cambridge: Cambridge University Press.

Machiavelli, Niccolò 1998[1513]. The Prince. (Mansfield, Harvey C., trans.) Chicago: The University of Chicago Press.

Martin, Conor 1952. The vulgate text of Aquinas's commentary on Aristotle's Politics. Dominican Studies 5: 35-64.

Momigliano, Arnaldo 1980. The fault of the Greeks. In: Momigliano, Arnaldo, Sesto contributo alla storia degli studi classici e del mondo antico. Vol. 2. Rome: Ed. di Storia e Letteratura, 509-524.

Nippel, Wilfried 1996. La costruzione dell' “altro”. In: Settis, Salvatore (ed.), I Greci. Storia, cultura, arte, società. Vol. 1: Noi e i Greci. Turin: Einaudi, 165-196.

Pagden, Anthony 1986. The Fall of Natural Man: The American Indian and the Origins of Comparative Ethnology. (Rev. ed.) Cambridge: Cambridge University Press.

Plato 1975[ca 350 BC]. The Statesman. (Fowler, Harold N., trans.) Cambridge: Harvard University Press.

Robinson, Thomas M. 1979. Contrasting Arguments. An Edition of the Dissoi Logoi. New York: Arno Press.

Sepúlveda, Juan Ginés de 1975[1550]. Apologia Joannis Genesii Sepulvedae pro libro de iustis belli causis. Romae, 1550. In: Sepúlveda, Juan Ginés de; Las Casas, Bartolomé de. Apologia. (Losada, Ángel, ed.) Madrid: Editora Nacional. 
Sepúlveda, Juan Ginés de 2009[1544]. Democrate secondo ovvero sulle giuste cause di guerra. (Taranto, Domenico, ed.) Macerata: Quodlibet.

The New Jerusalem Bible 1985. (Wansbrough, Henry, ed.) New York: Doubleday.

Thomas Aquinas 1492[ca 1272]. Commentaria in libros octo Politicorum Aristotelis. Rome.

- 1951[ca 1272]. In libros Politicorum Aristotelis expositio. (Spiazzi, Raimondo, ed.) Turin: Marietti.

Todorov, Tzvetan 1982. La Conquête de l'Amérique. Paris: Seuil.

Tuck, Richard 1999. The Rights of War and Peace: Political Thought and the International Order from Grotius to Kant. Oxford: Oxford University Press.

Untersteiner, Mario 1967. I sofisti: testimonianze e frammenti. Vol. 2. (Rev. ed.). Milan: Mondadori.

Vasoli, Cesare 1972. Leonardo Bruni. In: Dizionario biografico degli italiani. Vol. 14. Rome: Istituto della Enciclopedia Italiana, 618-633.

\section{Цивилизация и варварство}

Рассуждения о цивилизации, варварстве и их сложных взаимоотношениях, которые выдвигались в Древней Греции от Геродота до Аристотеля, возымели долгосрочные последствия. В дебатах о статусе коренных народов Нового Света, состоявшихся в Вальядолиде в середине 16 века между Хуаном Гинесом де Сепульведой и Бартоломе де Лас Касасом, особенно актуальными для обоих противников оказались латинские переводы «Политики» Аристотеля и комментарии к ней Фомы Аквинского. Были ли индейцы сопоставимы с «рабами по природе» Аристотеля? Была ли война против них сопоставимой с охотой на диких зверей? В статье основное внимание уделяется обсуждению дебатов и их современным последствиям.

\section{Tsivilisatsioon ja barbaarsus}

Antiik-Kreekas Herodotosest Aristoteleseni välja pakutud mõtisklustel tsivilisatsioonist, barbaarsusest ja nende omavahelisest keerukast suhtest oli kaugeleulatuv mõju. 16. sajandi keskel Valladolidis Juan Ginés de Sepúlveda ja Bartolomé de Las Casase vahel aset leidnud debatis Uue Maailma põliselanikkonna staatuse üle osutusid mõlema vastase jaoks eriti oluliseks Aristotelese "Poliitika" tõlked ladina keelde ja Aquino Thomase kommentaar sellele. Kas indiaanlastest põliselanikke võis kõrvutada Aristotelese "loomupäraste orjadega"? Kas sõda nende vastu võis kõrvutada metsloomade küttimisega? Artiklis keskendutakse debatile ning selle kaasaegsetele implikatsioonidele. 